\title{
Sentinel-1 Satellite Radar Images: a New Source of Information on River Channel Dynamics: Lower Vistula River, Poland.
}

\author{
Klaudia Kryniecka ${ }^{1}$, Artur Magnuszewski ${ }^{1}$, and Artur Radecki-Pawlik ${ }^{2}$ \\ ${ }^{1}$ University of Warsaw \\ ${ }^{2}$ Tadeusz Kosciuszko Cracow University of Technology Faculty of Civil Engineering
}

July 29, 2021

\begin{abstract}
The amount of sediments transported by a river is very difficult to estimate, however this parameter has an important influence on channel geometry. It is possible to estimate the bedload transport rate per unit width of a river channel by measuring bedform profiles' migration distance $(\Delta \mathrm{l})$ in time $(\Delta \mathrm{t})$ and depth of bedload in motion (hb). Another method is instrumental measurements using bedload traps and empirical formulas. Sentinel-1 images at mid latitudes have a temporal resolution of 2-3 days and spatial resolution of $25 \mathrm{~m}$, which allows them to be used on large rivers. The research area in this paper is the Lower Vistula River from $\mathrm{km} 814$ to $\mathrm{km} \mathrm{820,} \mathrm{where} \mathrm{seven} \mathrm{alternate} \mathrm{sandbars} \mathrm{were} \mathrm{selected.} \mathrm{The} \mathrm{coast} \mathrm{lines} \mathrm{of} \mathrm{the} \mathrm{sandbars}$ were delineated on Sentinel-1 images taken during two low flow periods 2018.08.04-09.26 and 2019.07.01-08.31 with similar discharges at low flow phase on the hydrograph. From water stage observations at the Chełmno and Grudziadz gauge stations, water elevations were assigned to every coast line of the alternate sandbars. The centers, volumes and longitudinal profile of the alternate sandbars were calculated. Average daily movement of the sandbars in the period 2018.08.04-2019.07.01 was calculated as $0.97 \mathrm{~m} \cdot \mathrm{day}-1$. Similar alternate sandbar movement velocities were obtained from a study of Sentinel-2 optical satellite images and hydro-acoustic measurements on the Lower Vistula River. Having the height of the alternate sandbars and velocity of movement, it was possible to calculate the rate of the bedload transport as $\mathrm{qb}=5 \mathrm{~kg} \cdot \mathrm{s}-1 \cdot \mathrm{m}-1$. This value is similar to results of empirical formulas accepted for use on large lowland rivers in Poland: Goncarov $-5 \mathrm{~kg} \cdot \mathrm{s}-1 \cdot \mathrm{m}-1, \mathrm{Samov}-$ $3 \mathrm{~kg} \cdot \mathrm{s}-1 \cdot \mathrm{m}-1$; Meyer-Peter and Müller $-9 \mathrm{~kg} \cdot \mathrm{s}-1 \cdot \mathrm{m}-1$; Skibiński (1976) - $15 \mathrm{~kg} \cdot \mathrm{s}-1 \cdot \mathrm{m}-1$. The novelty of this research is showing the use of Sentinel-1 images for the study of river channel dynamics and calculation of bedload transport.
\end{abstract}

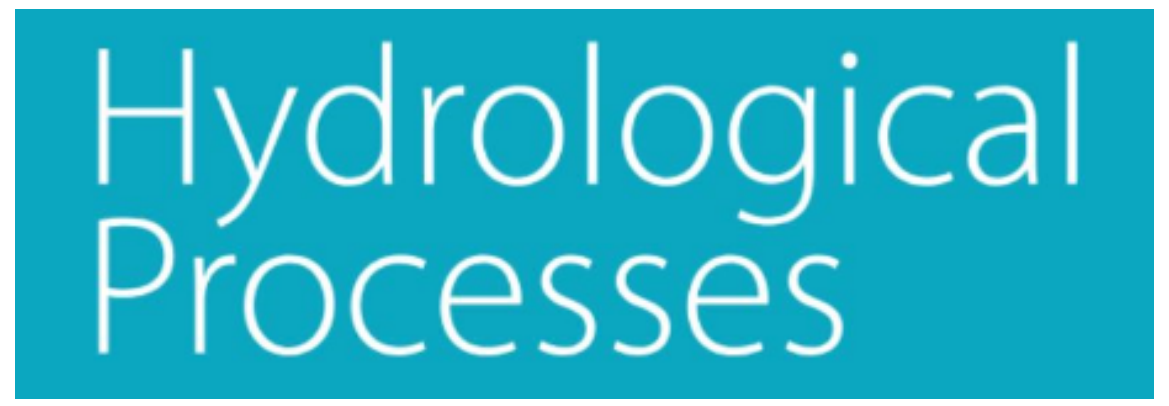

\section{Sentinel-1 Satellite Radar Images: a New Source of Information on River Channel Dynamics: Lower Vistula River, Poland}

Klaudia Kryniecka ${ }^{1}$, Artur Magnuszewski ${ }^{1}$, Artur Radecki-Pawlik ${ }^{2}$ 
${ }^{1}$ Hydrology Department, Faculty of Geography and Regional Studies, University of Warsaw, Krakowskie Przedmieście 30, 00-927 Warsaw, Poland

${ }^{2}$ Division of Structural Mechanics and Material Mechanics, Faculty of Civil Engineering, Cracow University of Technology, Warszawska 24, 31-155 Krakow, Poland

Corresponding Author : Artur Magnuszewski, asmagnus@uw.edu.pl

\section{Abstract}

The amount of sediments transported by a river is very difficult to estimate, however this parameter has an important influence on channel geometry. It is possible to estimate the bedload transport rate per unit width of a river channel by measuring bedform profiles' migration distance $(\Delta \lambda)$ in time $(\Delta \tau)$ and depth of bedload in motion $\left(h_{b}\right)$. Another method is instrumental measurements using bedload traps and empirical formulas. Sentinel-1 images at mid latitudes have a temporal resolution of 2-3 days and spatial resolution of $25 \mathrm{~m}$, which allows them to be used on large rivers. The research area in this paper is the Lower Vistula River from $\mathrm{km} 814$ to $\mathrm{km} \mathrm{820,} \mathrm{where} \mathrm{seven} \mathrm{alternate} \mathrm{sandbars} \mathrm{were} \mathrm{selected.} \mathrm{The} \mathrm{coast} \mathrm{lines} \mathrm{of} \mathrm{the} \mathrm{sandbars}$ were delineated on Sentinel-1 images taken during two low flow periods 2018.08.04-09.26 and 2019.07.0108.31 with similar discharges at low flow phase on the hydrograph. From water stage observations at the Chełmno and Grudziadz gauge stations, water elevations were assigned to every coast line of the alternate sandbars. The centers, volumes and longitudinal profile of the alternate sandbars were calculated. Average daily movement of the sandbars in the period 2018.08.04-2019.07.01 was calculated as $0.97 \mathrm{~m} \cdot$ day $^{-1}$. Similar alternate sandbar movement velocities were obtained from a study of Sentinel-2 optical satellite images and hydro-acoustic measurements on the Lower Vistula River. Having the height of the alternate sandbars and velocity of movement, it was possible to calculate the rate of the bedload transport as $q_{b}=5 \mathrm{~kg} \cdot \mathrm{s}^{-1} \cdot \mathrm{m}^{-1}$. This value is similar to results of empirical formulas accepted for use on large lowland rivers in Poland: Goncarov $-5 \mathrm{~kg} \cdot \mathrm{s}^{-1} \cdot \mathrm{m}^{-1}$, Samov $-3 \mathrm{~kg} \cdot \mathrm{s}^{-1} \cdot \mathrm{m}^{-1}$; Meyer-Peter and Müller $-9 \mathrm{~kg} \cdot \mathrm{s}^{-1} \cdot \mathrm{m}^{-1}$; Skibiński $(1976)-15 \mathrm{~kg} \cdot \mathrm{s}^{-1} \cdot \mathrm{m}^{-1}$. The novelty of this research is showing the use of Sentinel-1 images for the study of river channel dynamics and calculation of bedload transport.

Keywords: Lower Vistula River, alternate sandbars, Sentinel-1 radar satellite images

\section{Hosted file}

Main_text.docx available at https://authorea.com/users/428136/articles/532108-sentinel1-satellite-radar-images-a-new-source-of-information-on-river-channel-dynamics-lowervistula-river-poland

\section{Hosted file}

references.docx available at https://authorea.com/users/428136/articles/532108-sentinel1-satellite-radar-images-a-new-source-of-information-on-river-channel-dynamics-lowervistula-river-poland

\section{Hosted file}

Figures_Tables.docx available at https://authorea.com/users/428136/articles/532108-sentinel1-satellite-radar-images-a-new-source-of-information-on-river-channel-dynamics-lowervistula-river-poland 